\title{
Toward Religious Neutrality in the Public School Curriculum
}

\author{
Winton E. Yerby III†
}

Public school curriculum choices have been disputed since the inception of compulsory education. The growth of Catholic schools in the nineteenth century was a response to concerns over the Protestant ideology prevalent in the public school curriculum. ${ }^{1}$ During the 1960's, various minority groups recognized and reacted to racial and ethnic bias in school textbooks. ${ }^{2}$ In more recent years, interest groups from both the Right and the Left have attempted to remove objectionable textbooks from the classroom. ${ }^{3}$ The latest members of this long line of concerned parents have been conservative Christian groups.

In a series of recent lawsuits, these groups have questioned whether the curriculum used in the public schools fairly portrays religion. Although some have discounted these challenges as censorship or efforts to impose a fundamentalist ideology, ${ }^{4}$ contemporary curriculum attacks are quite similar, at least in form, to the complaints raised by prior groups. ${ }^{5}$ Yet since these recent charges have been directed specifically at the treatment of religion, they also implicate the religion clauses of the First Amendment. ${ }^{6}$

† B.A. 1986, Samford University; J.D. Candidate 1989, The University of Chicago.

${ }^{1}$ See Rockne M. McCarthy, James W. Skillen and William A. Harper, Disestablishment a Second Time: Genuine Pluralism for American Schools at 60-70 (Christian U, 1982), and F. Michael Perko, S.J., Schools in Trouble: Religious "Outsiders" Critique American Public Education, 27 Criterion 11 (Spring, 1988) for a discussion of the experience of Catholics in New York during the nineteenth century.

2 Frances FitzGerald, America Revised: History Schoolbooks in the Twentieth Century at 38-43 (Little Brown, 1979)("America Revised"); David L. Kirp and Mark G. Yudof, Educational Policy and the Law at 117 (McCutchan, 1974).

s John S. Simmons, Proactive Censorship: The New Wave, 70 Eng J 18, 19 (Dec, 1981). See also George Dent, Religious Children, Secular Schools, 61 S Cal L Rev 864, 927 (1988) (efforts to remove Huckleberry Finn and Merchant of Venice); Stephen Arons, Compelling Belief at 15 (McGraw-Hill, 1983) (politically motivated textbook requirements imposed by states).

4 James E. Wood, Jr., Religious Fundamentalism and the Public Schools, $29 \mathrm{~J}$ of Church and State 1, 12 (Winter, 1987).

- Perko, 27 Criterion at 14 (cited in note 1)(similarities between complaints of Catholics and fundamentalists).

- The First Amendment states in relevant part: "Congress shall make no law respecting 
The Establishment Clause requires the state to maintain a stance of neutrality between religion and non-religion. ${ }^{7}$ As applied to a school's curriculum, the clause prevents a public school from choosing textbooks and other curricular materials that have the effect of promoting or inhibiting religion. ${ }^{8}$ Conservative Christian groups complain that certain curricular materials used in the public schools coerce religious students by promoting "secular humanism," inhibiting traditional theistic religion or infringing free exercise rights. ${ }^{9}$

There are three responses to these challenges. At one extreme, any material found to offend the sensitivities of religious students could be excluded from the public schools. This, of course, could potentially undermine the viability of the public education. At the other extreme, any material that could possibly be categorized as non-religious could be deemed acceptable for public school use. This position would sharply limit constitutional protection for the sensitivities of religious students in a public school system whose curriculum, at least, is thoroughly secular. ${ }^{10} \mathrm{~A}$ third and intermediate position could balance religious sensitivities against the demands of the public school system. This comment will propose an Establishment Clause test that meets this third standard.11

This comment will focus on the materials and programs disputed in the cases brought by conservative Christian groups and will attempt to develop an Establishment Clause standard for reviewing the challenged materials. It will explore, for instance, whether there is a cognizable constitutional claim when history and social studies textbooks are challenged for omitting key facts about religious history, or whether home economics texts may teach value formation ${ }^{12}$ without reference to religious bases for

an establishment of religion, or prohibiting the free exercise thereof." US Const, Amend I, cl 1.

${ }^{7}$ See Abington School District v Schempp, 374 US 203, 226 (1963).

${ }^{-}$See Lemon v Kurtzman, 403 US 602, 612 (1971) and text accompanying notes 107-11.

- See cases cited in section I.

10 This assertion is based upon several recent studies of curriculum. See Paul C. Vitz, Censorship at 1-3 (Servant, 1986) (finding near total exclusion of religious references in public school textbooks).

11 This Comment will not address free exercise claims, although issues relevant to such claims will be discussed. Possession of an Establishment Clause claim would not diminish any free exercise claim the student may also possess.

12 "Value formation" refers to attempts to teach students how to form their own values. For instance, one text suggests teaching children that all values are subjective. This text explicitly rejects the idea that students should be taught through a "moralization," "laissezfaire" or "role model" method of value inculcation. See Sidney B. Simon, Leland W. Howe and Howard Kirschenbaum, Values Clarification: A Handbook of Practical Strategies for 
values.

Section I discusses the various religion clause claims raised by plaintiffs in recent cases challenging public school curricula. Section II discusses the general First Amendment concerns posed by public education and the possible judicial approaches that can be used to respond to concerns over the choice of curriculum. Against this background, section III discusses the specific role of the Establishment Clause in the shaping of curricula and examines judicial attempts to insure that public school education remains neutral towards religion. Section IV demonstrates the impossibility of providing the neutrality that the Establishment Clause theoretically requires. Finally, section $\mathrm{V}$ proposes a test that recognizes the inevitability of non-neutrality, yet balances the rights of religious students against the demands of public education.

\section{Recent Curriculum Challenges by Conservative Christians}

One of the most highly publicized curriculum challenges occurred in Smith $v$ Board of School Commissioners of Mobile County. ${ }^{13}$ The plaintiffs claimed that the local school textbooks endorsed secular humanism and rejected theism, thereby violating the Establishment Clause. Students, parents and teachers cast their complaints in various forms. One student plaintiff alleged that the school books offended him and sanctioned practices that were contrary to his beliefs. ${ }^{14}$ Teachers complained that the textbooks restricted their classroom offerings and compelled them to teach doctrines that were offensive to their religious beliefs. ${ }^{15}$ One parent complained that the conflict between family values and the values taught in the classroom brought his children to tears. ${ }^{16}$

The plaintiffs challenged various textbooks. They complained generally about home economics textbooks that taught that value formation was personal and subjective. These books created the impression that the "only commandment . . . is, 'don't forget value processing." "17 The plaintiffs challenged history and social study

Teachers and Students at 15-19 (Hart, 1972).

${ }^{13} 655$ F Supp 939 (S D Ala 1987), rev'd, 827 F2d 684 (11th Cir 1987).

14 Smith, 655 F Supp at $944-45$.

1s For instance, the teachers objected to material which stated that there is no absolute right or wrong and that it is proper to reject the authority of people in charge. Id at $\mathbf{9 4 5}$.

18 Id.

${ }^{17}$ Id at 974 . This claim was predicated upon such passages from the texts as: "Morals are rules made by people," id at 1003; "Values are personal and subjective. They vary from person to person," id at 1004; "Standards are a personal decision and will vary with each 
textbooks as omitting "numerous significant facts about religion and religious contribution to American history." 18 The plaintiffs argued that these and other textbooks established secularism to the exclusion of religion in the public schools. ${ }^{19}$

The trial court in Smith found that the plaintiffs sought only "objective education, not partisan indoctrination." 20 The court decided that "[f]or purposes of the first amendment, secular humanism is a religious belief system, entitled to the protection of, and subject to the prohibitions of, the religion clauses." ${ }^{21}$ It found that the significant omissions in the school history textbooks "discriminate[d] against the very concept of religion, and theistic religions in particular. ..."22 The social studies textbooks were so inaccurate as "to give rise to a constitutional violation," and the home economics textbooks implied "strongly that a person uses the same process in deciding a moral issue that he uses in choosing one pair of shoes over another." "23 "The court held that the content of the textbooks reflected an "assumption based on a particular vision of human nature unrelated to science."24 The court continued: "Teaching that moral choices are purely personal and can only be based on some autonomous, as yet undiscovered and unfulfilled, inner self is a sweeping fundamental belief that must not be promoted by the public schools." 25 The court concluded that the text-

person," id at 1003. The texts also stressed modern psychology: "Self-actualization is the highest level of human need." Id at 1000. Dr. William Coulson of United States International University stated that the philosophy of the textbooks was "that only you can judge your values, you are the designer of your life, you are the most important person in your life. ..." Id at 957. He considered this an "unfounded faith claim." Id at 960.

${ }^{18}$ Id at 983.

18 Expert testimony was used to support the claims. Harvard psychologist Robert Coles stated in a deposition that the textbooks contained a quantity of "social and cultural rot." Id at 960 . Dr. Richard Baer of Cornell University reviewed the challenged home economics textbooks and testified that they were linked closely with the philosophy of hedonism. Id at 957. .

20 Id at 975.

21 Id at 982.

${ }^{22}$ Id at 985. The court acknowledged that "[m]ere rotten and inadequate textbooks ... have not yet been determined to violate any constitutional provision, much less the religion clauses." Id at 983. The Court, however, citing Epperson v Arkansas, 393 US 97 (1968), held that omissions "can constitute a first amendment violation," and that in this case the textbooks lacked "so many facts as to equal ideological promotion." Id at 983-85.

${ }^{23}$ Id at 986 . This finding was based on a passage in one of the texts which stated: "As you can see, the steps in decisionmaking can be applied to something as simple as buying a new pair of shoes. They can also be applied to more complex decisions such as those which involve religious preferences. ..." Id at 1005, quoting Frances Baynor Parnell, Homemaking Skills for Everyday Living at 26 (Goodheart-Willcox, 1984).

${ }^{24} 655$ F Supp at 986.

${ }^{25}$ Id at 987. 
books established secular humanism in the Mobile County schools and barred their use absent implementation of a comparative approach. ${ }^{26}$

On appeal, the Eleventh Circuit held that the plaintiffs failed to establish a constitutional claim. ${ }^{27}$ The Court focused on whether the textbooks advanced or inhibited religion, and found that they had the "primary effect of conveying information that is essentially neutral in its religious content to the school children who utilize [them]. ..."28 The court reasoned that statements such as, "You are the most important person in your life" were only meant to instill in school children the "secular" values of independent thought, tolerance, self-respect, and maturity. ${ }^{29}$ So long as such statements promoted neutral values, the mere fact that they were also consistent with secular humanism was constitutionally irrelevant. ${ }^{30}$ Moreover, "neutrality" could never amount to an inhibition of religion. ${ }^{31}$ Using an objective person standard, the Eleventh Circuit also found no disapproval of theism in the mere omission of historical facts. ${ }^{32}$ The court concluded by stating that the Establishment Clause did not require "equal time" for religion. ${ }^{33}$

In Mozert $v$ Hawkins County Public Schools, ${ }^{34}$ plaintiffs waged a similar attack on secular humanism. Using a free exercise argument, the parents objected to the discussion in textbooks of such themes as moral relativism, evolution, sex role reversal, and mental telepathy. The district court, finding that these themes were not isolated, stated that "[o]ne story reinforces and builds upon the other throughout the individual texts and the series as a whole."35 Taken together, the textbooks were thus incompatible with the religious students' sensitivities. The court issued an injunction requiring the defendant school to excuse the plaintiff children from the class. ${ }^{36}$ 1987).

26 Id at 990.

${ }^{27}$ Smith v Board of School Commissioners of Mobile County, 827 F2d 684 (11th Cir

${ }^{28} \mathrm{Id}$.

29 Id at 692.

so Id.

${ }^{31}$ Id, citing McCollum $v$ Board of Education, 333 US 203, $211-12$ (1948).

32 Smith, 827 F2d at 694.

${ }^{33}$ Id at 695.

34 647 F Supp 1194 (E D Tenn 1986),rev'd, 827 F2d 1058 (6th Cir 1987). Free exercise analysis requires a compelling state interest to justify a burden on the claimant's ability to exercise his or her religious beliefs. Thomas $v$ Review Board, 450 US 707, 717-18 (1981).

${ }^{35}$ Mozert, $647 \mathrm{~F}$ Supp at 1199.

ss Id at 1203. The district court also provided for a hearing for damages against the school. Id at 1204. 
The Sixth Circuit reversed, finding that reading the textbooks did not entail an "affirmation or denial of a religious belief."37 Since the students were not compelled to believe what they read, a requirement that they learn objectionable themes provided an insufficient basis for a constitutional claim. ${ }^{38}$ Other courts have rejected constitutional claims as well. In Williams $v$ Board of Education of County of Kanawha, plaintiffs challenged a textbook that contained "religious and anti-religious matter, matter offensive to Christian morals ... and stories promoting and encouraging a disbelief in a Supreme Being . . . ."39 Using a mixture of establishment and free exercise claims, the plaintiffs sought an injunction against this promotion of "anti-religion" and disbelief. The court summarily dismissed the claims, stating: "A complete loosening of imagination is necessary to find that placing the books and materials in the schools constitutes an establishment of religion contrary to the rights contained in the Constitution .... [T] he [First] Amendment does not guarantee that nothing about religion will be taught in the schools. . .."40

In Grove v Mead School District No. 354, parents used both establishment and free exercise claims to urge the banning of a novel used in a sophomore English class. ${ }^{41}$ A Ninth Circuit panel rejected the Free Exercise claim because the objecting student had been excused from reading the book and complete accommodation of the student's beliefs would have constituted too heavy a burden on the school. ${ }^{42}$ The Establishment Clause claim failed because the book in question was not primarily concerned with religious matters. ${ }^{43}$

The basic thrust of all these curriculum attacks is that secularism affects religious students in much the same way as Bible reading and voluntary prayer affect non-religious students. Most courts have rejected such an analogy, declining to articulate any

${ }^{37}$ Mozert, 827 F2d 1058, 1065 (6th Cir 1987).

${ }^{38}$ Id at $1066,1070$.

39 388 F Supp 93, 94-95 (S D W Va 1975), aff'd without opinion, 530 F2d 972 (4th Cir 1975).

to 388 F Supp at 96 .

${ }^{41} 753$ F2d 1528 (9th Cir 1985). The book was The Learning Tree by Gordon Parks. Id at 1531 .

42 Id at 1533-34.

${ }^{43}$ Id at 1534. In a concurring opinion, Judge Canby argued that the plaintiffs' claims were fatally flawed because they failed to distinguish between "religious," "nonreligious," and "anti-religious" government action, thus preventing a meaningful application of the Establishment Clause. He also felt that the mere inclusion of the book in the literature class was insufficient to establish governmental "disapproval" of religion. Id at 1536-37. 
fact pattern that might constitute a non-religious establishment or an interference with students' religious beliefs. Courts have not applied a coherent standard in analyzing the fact patterns that have come before them, however. The Eleventh Circuit held in Smith that the values inculcated by the schools were neutral, and thus immune from attack. ${ }^{44}$ The Sixth Circuit held in Mozert that successful assertion of a free exercise claim required affirmation or denial of a religious belief. ${ }^{45}$ By relying upon ambiguous terms like "neutrality" and "affirmation or denial," these courts have failed to confront the real harm that religious students may suffer.

\section{Public Schools and Freedom of Speech}

Although this comment addresses Establishment Clause constraints on the discretion of local school boards, Supreme Court jurisprudence on the relationship between students' constitutional rights and the state's ability to make curriculum choices has developed primarily in the context of due process and First Amendment free speech claims. Although the Court has not reached a consensus in cases involving such claims, it has sought to balance the government's duty to educate against the student's right to be free of coercive indoctrination. These cases provide a helpful backdrop for Establishment Clause analysis by illustrating the tension inherent in all curriculum choices. They also demonstrate potential judicial responses to such tension.

\section{A. Public Education and Value Formation}

The fact that compulsory education laws did not become widespread until the twentieth century ${ }^{46}$ should not undermine states' assertions of a compelling interest in ensuring that citizens acquire certain basic skills. ${ }^{47}$ Mere attendance in public schools inevitably subjects school children to more than the teaching of basic skills, however; significant socialization, whether carried out consciously or not, accompanies traditional education. ${ }^{48}$

14 Smith, 827 F2d at $689-90$.

15 Mozert, 827 F2d at 1070.

16 Kirp and Yudof, Educational Policy and the Law at 5-6 (cited in note 2).

${ }^{47}$ See Wisconsin v Yoder, 406 US 205, 221 (1972); Pierce $v$ Society of Sisters, 268 US 510,534 (1925). The state's interest is compelling insofar as it requires its citizens to be able to read, write, and perform basic tasks. Dent, $61 \mathrm{~S} \mathrm{Cal} \mathrm{L} \mathrm{Rev} \mathrm{at} 905$ (cited in note 3). What the state can require of such institutions as private schools tends to be very general. Id at 911 and 974. See Kentucky State Board v Rudasill, 589 SW2d 877 (Ky 1979) (state interest does not extend to review of textbooks or teacher certification).

4 For a discussion of the values which are taught unconsciously through the "hidden 
The Supreme Court has recognized that education is a primary means of transmitting cultural heritage to new generations. ${ }^{49}$ But the Court has also approved, at least in dictum, the state's attempts to consciously inculcate values in the schools, noting that there is a "legitimate and substantial community interest" in promoting "values," whether they be "social, moral, or political." The Court considers the public schools essential vehicles for "inculcating fundamental values necessary to the maintenance of a democratic political system. . .."51

This ambiguous power to inculcate "democratic" values has not provided the state with a carte blanche power over school children. Most significantly, the state must not infringe on the parents' ultimate right to control and direct the education of their children. In Pierce $v$ Society of Sisters, ${ }^{52}$ the Court, using substantive due process analysis, struck down a state law requiring all children to attend public schools. The Court stated:

[T] he [A]ct ... unreasonably interferes with the liberty of parents and guardians to direct the upbringing and education of children under their control .... The fundamental theory of liberty upon which all governments in this Union repose

curriculum," see Stephen Arons and Charles Lawrence, The Manipulation of Consciousness: A First Amendment Critique of Schooling, 15 Harv CR-CL L Rev 309, 317 (1980) (hidden curriculum includes role models, structure, school government, attitudes that are rewarded). It is probably impossible to prevent both the conscious and unconscious indoctrination of values that occurs within the public schools. See David Purpel and Kevin Ryan, Moral Education... It Comes with the Territory at 53 (McCutchan, 1976) (The question is not "should we have moral education in the schools?' but rather 'to what degree and in what dimension and areas should we deal with moral education in the schools?" "); Dent, $61 \mathrm{~S} \mathrm{Cal}$ L Rev at 908-09 (cited in note 3) ("The only way to prevent public schools from teaching values would be to abolish public schools."); and Amy Gutmann, Democratic Education at 41, 54 (Princeton, 1988).

49 Ambach v Norwick, 441 US 68, 77-78 (1979). See also Kirp and Yudof, Educational Policy and the Law at 88-93 (cited in note 2), quoting Richard E. Dawson, Kenneth Prewitt, and Karen S. Dawson, Political Socialization at 5-6, 146-66 (Little Brown, 2d ed 1977); Gutmann, Democratic Education at 52 (cited in note 48).

so Board of Education v Pico, 457 US 853, 864 (1982). This "duty" to inculcate values has often been noted by the Court. In Brown v Board of Education, 347 US 483, 493 (1953), the Court held out education as the "very foundation of good citizenship . . . a principal instrument in awakening the child to cultural values, in preparing him for later professional training, and in helping him to adjust normally to his environment."

${ }^{51}$ Ambach, 441 US at 77 (1979). The Court thus finds a connection between inculcating values and preserving democracy. See also School Dist No 403 v Fraser, 478 US 675, 681 (1986). This justification for inculcating values has been disputed, however. See Tyll van Geel, The Search for Constitutional Limits on the Governmental Authority to Inculcate Youth, 62 Tex L Rev 197, 262-89 (1983) (no empirical basis for belief that inculcation of values is necessary for the preservation of democracy).

${ }^{\text {s2 } 2} 268$ US 510 (1925). 
excludes any general power of the State to standardize its children by forcing them to accept instruction from public teachers only. The child is not the mere creature of the State; those who nurture him and direct his destiny have the right, coupled with the high duty, to recognize and prepare him for additional obligations. ${ }^{\text {s3 }}$

Pierce indicates that whatever interest the state does have in indoctrination is not so compelling that it trumps a fundamental liberty interest.

The Supreme Court has also made it clear that practices in the public schools must conform to the dictates of the First Amendment. In Board of Education v Barnette, ${ }^{54}$ the Court struck down a flag salute and pledge of allegiance requirement, stating:

If there is any fixed star in our constitutional constellation, it is that no official, high or petty, can prescribe what shall be orthodox in politics, nationalism, religion, or other matters of opinion or force citizens to confess by word or act their faith therein .... We think the action of the local authorities in compelling the flag salute and pledge transcends constitutional limitations on their power and invades the sphere of intellect and spirit which it is the purpose of the First Amendment to our Constitution to reserve from all official control. ${ }^{55}$

Thus, the discretion possessed by local authorities to inculcate values is limited by the First Amendment and the Due Process Clause. Certain free speech rights of students ${ }^{56}$ and teachers ${ }^{57}$ also impede the state's ability to promote uniform values.

The Court's hesitancy to grant complete discretion to local officials stems from a recognition of the First Amendment tensions

${ }^{53}$ Id at 534-35. See also Carey v Population Services International, 431 US 678, 684-85 (1977) (child rearing and education are within liberty principle).

s4 319 US 624 (1943).

ss Id at 642. The Court acknowledged some power to inculcate, noting that the school may "require teaching . . . which tend[s] to inspire patriotism and love of country," id at 631, quoting Minersuille School District v Gobitis, 310 US 586 (1940) (Stone dissenting).

${ }_{68}$ In Tinker $v$ Des Moines Independent Community School District, 393 US 503 (1969), students challenged the local school board's attempt to prohibit the wearing of armbands as an expression of opposition to the Vietnam War. In rejecting the prohibition, the Court noted that students were not "confined to the expression of those sentiments that are officially approved." Id at 511.

${ }^{37}$ Ambach v Norwick, 441 US 68 (1979). But see Stephen R. Goldstein, The Asserted Constitutional Right of Public School Teachers to Determine What They Teach, $124 \mathrm{U} \mathrm{Pa}$ L Rev 1293, 1341-44 (1976) (arguing that primary and secondary school teachers have no interest in academic freedom because the purpose of educating children is the inculcation of values). 
that arise whenever the government speaks. Effective governments must be allowed to communicate substantive ideas to their citizens, $^{58}$ and the public schools are an important locus for such communication. ${ }^{59}$ But government speech in the public school context raises two concerns not generally present in other instances of government indoctrination. First, school children are particularly vulnerable to indoctrination. Public schools are in a sense a "communication theorist's" dream. ${ }^{60}$ Students are at a particularly impressionable age and are made a captive audience within a hierarchical organization, ${ }^{61}$ often far removed from their "community, [both] physically and emotionally." 62 The authority figures within this hierarchy force students to learn and recite doctrines for grades. ${ }^{63}$ Believing that students require extra constitutional protection under these circumstances, the courts have often fashioned special rules for the public schools. ${ }^{64}$

Second, education poses a possible threat to cultural identity. Education is a means of enculturation, and mandatory uniform schooling can undermine a student's basic cultural values, thereby "manipulating" his or her consciousness. ${ }^{65}$ This in turn poses a threat to a democratic society, where the ability to think independently is critical. ${ }^{66}$ If the state can coerce the formation of ideas

в8 See Mark G. Yudof, When Governments Speak, 57 Tex L Rev 863, 898 (1979) (arguing that consequences of eliminating government speech are worse than potential threat posed by government speech).

${ }^{58}$ Mark G. Yudof, When Government Speaks at 213-33 (U Cal, 1983); Yudof, 57 Tex L Rev 874-90 (cited in note 58); Steven Shiffrin, Government Speech, 27 UCLA L Rev 565, 647-53 (1980).

60 Yudof, When Government Speaks at 213 (cited in note 59). The schools cannot completely indoctrinate, of course, as students are only in school part of the day and have access to information outside of the school. Id.

${ }^{61}$ Edwards v Aguillard, 482 US 578, 107 S Ct 2573, 2577 (1987).

62 Wisconsin $v$ Yoder, 406 US 205, 211 (1972).

${ }^{63}$ Yudof, When Government Speaks at 213 (cited in note 59); Nadine Strossen, "Secular Humanism" and "Scientific Creationism," 47 Ohio St L J 333, 370 (1986). The coercive, hierarchical and somewhat alienating nature of schools makes them analogous to prisons and the military. Special allowances are made for religious practice in both of these contexts. See Cruz v Beto, 405 US 319, 322 n 2 (1972) (inmates must be given "reasonable opportunity" to "exercise . . religious freedom"); O'Lone v Estate of Shabazz, 482 US 342, 107 S Ct 2400, 2406 (1987); Katcoff $v$ Marsh, 755 F2d 223, 226-27 (2d Cir 1985) (military chaplains may be required by the Free Exercise Clause). For the argument that special dispensation should be made for religious practice in the public schools, where government also has a pervasive presence, see Michael W. McConnell, Neutrality Under the Religion Clauses, $81 \mathrm{Nw}$ U L Rev 146, 161-62 (1986).

of Aguillard, $107 \mathrm{~S}$ Ct at 2577.

os Arons and Lawrence, 15 Harv CR-CL L Rev at 312-13 (cited in note 48).

${ }^{68}$ See Yudof, 57 Tex L Rev at 897-98 (cited in note 58). See also Alexander Meiklejohn, The First Amendment Is An Absolute, 1961 S Ct Rev 245, 257-58; Rogers v Okin, 478 F 
through indoctrination, freedom of expression may become meaningless. ${ }^{67}$ Unless there is a realm of existence that is insulated from government, the state, particularly in a technologically sophisticated age, will present an increasing threat to personal liberty. ${ }^{68}$ In this light, the Court's holding in Pierce stands not so much for the proposition that parents have an absolute right to educate their children, but that the government should not be given a monopoly over all aspects of educational development. ${ }^{69}$

The public school is caught, therefore, in an uneasy position. It has the right, the duty, and probably the inevitable task of inculcating basic community values, or at least certain "democratic values." On the other hand, a school cannot impose orthodoxy or infringe basic constitutional rights. ${ }^{70}$ The courts have done very little to reconcile these possibly irreconcilable duties, and there is no consensus on the degree of judicial intervention necessary to maintain a proper balance between them. The resulting tension infuses choices about a school's curriculum.

\section{B. The Special Problem of Curriculum.}

In choosing a particular curriculum, especially one that includes prescriptive texts, the state makes a conscious determination of which values it will inculcate. ${ }^{71}$ The only Supreme Court precedent dealing with general review of curriculum choices is Board of Education $v$ Pico, ${ }^{72}$ a case decided on general First Amendment grounds. In Pico, the school board removed several

Supp 1342, 1367 (D Mass 1979) (free expression presupposes capacity to produce ideas).

${ }^{67}$ See Arons and Lawrence, 15 Harv CR-CL L Rev at 312 (cited in note 48).

os See id at 313; Yudof, When Government Speaks at 10-12 (cited in note 59); Yudof, 57 Tex L Rev at 873 (cited in note 58) (greatest threat to system of free expression emanates from welfare state).

60 Yudof, 57 Tex L Rev at 889-90 (cited in note 58).

${ }^{70}$ For instance, a school may teach that treason is wrong but it is probably unconstitutional to discourage resistance to an unpopular war. See Tinker, 393 US at 509-11. A school can also inculcate basic "American" values but cannot go so far as to ban foreign languages. See Meyer $v$ Nebraska, 262 US 390, 401-03 (1923).

72 In Ambach, the Court noted the conscious use of curriculum to inculcate values: "The curriculum requirements of New York's public school system ... promote the development of the understanding that is prerequisite to intelligent participation in the democratic process." 441 US at $78 \mathrm{n} 8$. See also Thomas I. Emerson and David Haber, The Scopes Case in Modern Dress, 27 U Chi L Rev 522, 527 (1960) ("The government itself determines what the content of the communication should be throughout a major portion of our educational system.") The choice of which orthodoxy to enshrime in the curriculum is the modern analogue to the establishment of a state church. Such an analogy helps explain why curriculum choices create such controversy. Arons, Compelling Belief at 20 (cited in note 3).

72457 US 853 (1982). 
books from the school library. A group of students challenged the action as a violation of their First Amendment rights, alleging that the Board members removed the books because they "offended their social, political and moral tastes and not because the books, taken as a whole, were lacking in educational value."73

The district court found that removal of the books fell within the school board's discretion. The Second Circuit reversed and remanded, finding that the record indicated that the school board was motivated by moral and political beliefs. ${ }^{74}$ The Supreme Court affirmed the Second Circuit's decision ordering a new trial. The Court split 5-4, however, and filed seven separate opinions, none of which commanded a majority.

Justice Brennan, joined by Justices Marshall and Stevens, authored the plurality opinion ${ }^{75}$ recognizing local school board discretion but requiring it to "be exercised in a manner that comports with the transcendent imperatives of the First Amendment." plurality distinguished library book removal questions from curriculum questions. Placing special emphasis on the fact that the book was in the school library and held that removing the book violated the students' First Amendment "right to receive information and ideas." "7?

The plurality limited judicial review to scrutiny of a school board's motives, however, holding that a board violates the Constitution if its members "intended by their removal decision to deny respondents access to ideas with which [the board] disagree[s], and if this intent [was] the decisive factor ...." The plurality also cautioned that the Board's "discretion may not be exercised in a narrowly partisan or political manner."78

The dissenting opinions of Justices Burger, Powell, Rehnquist, and O'Connor rejected both the "right to know" model and the plurality's distinction between libraries and the general curriculum. They argued that if the concern is preventing infringement of the right to receive information, then the acquisition of biased

${ }^{73}$ Id at 858-59.

74 Id at 860-61 n 16.

78 Justice White concurred in the judgment on procedural grounds. Id at 883-84.

26 Id at 863-64.

77 Id at 861-62, 867, quoting Stanley v Georgia, 394 US 557, 564 (1969) and citing Kleindienst $v$ Mandel, 408 US 753, 762-63 (1972).

${ }^{78}$ Id at 871 (emphasis in original).

79 Id at 870. Justice Blackmun concurred, basing his decision not on a broad "right to know" but on the fact that the state affirmatively singled out certain books for disapproval. He accepted the plurality's motivation test. Id at 879-81. 
books for the curriculum can result in the suppression of ideas far more easily than mere removal of books from the library. ${ }^{80}$ The dissents emphasized the importance of a local school board's power to inculcate values. ${ }^{81}$

Justice Rehnquist conceded that there may be constitutional restrictions on local discretion in "extreme" cases but argued that the court was not faced with such a situation..$^{82}$ Rehnquist also distinguished between elementary and secondary schools, which are dedicated to the teaching of "basic skills and ideas," and universities and public libraries, designed for "freewheeling inquiry."83 Rehnquist suggested that removal decisions in this latter category of institutions may be subject to greater scrutiny. ${ }^{84}$

One can glean from the various opinions in Pico three potential responses to the issue of government speech in the schools. At one extreme, the courts could impose direct limits on the state's power to indoctrinate by granting to students an expansive "right to receive ideas" derived from various First Amendment theories. ${ }^{85}$ Since what a student receives is very much dependent on what the school chooses to let him or her receive, this approach imposes an affirmative duty on schools to provide an objective, balanced treatment of any important subject dealt with in the curriculum. ${ }^{86} \mathrm{Al}$ though no court has adopted this position fully, ${ }^{87}$ several commentators have supported such a balanced presentation approach. ${ }^{88}$

so Id at $892-93,895,916-17,921$.

81 Id at 889 (Burger, Rehnquist and O'Connor dissenting); id at 896 (Powell dissenting).

${ }^{82}$ Id at 907 .

83 Id at 915.

84 Id. Justice O'Connor seemed to take the most extreme position, stating that the elected school board may set the curriculum "so long as it does not also interfere with the right of students to read the material and to discuss it." Id at 921.

${ }^{85}$ See van Geel, 62 Tex L Rev at 231 (cited in note 51); Norman B. Lichtenstein, Children, the Schools, and the Right to Know: Some Thoughts at the Schoolhouse Gate, 19 USF L Rev 91, 129 (1985).

${ }^{88}$ This approach has the advantage of obviating the need for neutral principles by which to judge curriculum choices. The difficulty with this position is that it totally rejects the traditional role of the school as the inculcator of community values. The potential disruption of education due to constant litigation may also make this approach unreasonable.

${ }^{87}$ In Minarchini v Strongsville City School District, 541 F2d 577 (6th Cir 1976), the Sixth Circuit decided that the local school board's discretion to remove books from the school library was quite limited. The court held that students have a general First Amendment right to receive information, which is violated when books are removed from the library for reasons of "social or political tastes." Id at 582. Other cases taking a similar position include Sheck v Baileyville School Committee, 530 F Supp 679 (D Me 1982); Salvail v Nashua Board of Education, 469 F Supp 1269 (D NH 1979).

${ }^{88}$ For an example of a balanced presentation approach applied to schools, see van Geel, 62 Tex L Rev at 289-92 (cited in note 51) (proposing a "fairness principle" for public schools). For other proposals, see Emerson and Haber, 27 U Chi L Rev at 527 (cited in note 
An intermediate position would protect students from some indoctrination by focusing on the motives behind school board decisions. If a school board made a narrowly partisan decision or tried to impose a "pall of orthodoxy," then the courts could step in to review such egregious cases. ${ }^{89}$ At the other extreme is the dissenters' position in Pico. Under this view, the school board receives almost total insulation from review of its curriculum decisions. ${ }^{90}$ This approach is difficult to reconcile with Supreme Court precedents recognizing some general constitutional limitations on the inculcative practices of school boards. ${ }^{91}$

Although one cannot completely derive the mandates of the Establishment Clause from general First Amendment principles, the Court's response in Pico provides a framework for analyzing the extent to which courts can intervene to protect students from curriculum decisions affecting their constitutional rights.

\section{The Establishment Clause and Public Schools}

In contrast to the deference the Court has granted school boards in considering general First Amendment claims of indoctrination, the Court has remained vigilant with regard to Establishment Clause violations in the public schools. This vigilance is pred-

71)(advocating "a fairly balanced exposition of various theories and points of view"); Note, Challenging Ideological Exclusion of Curriculum Material, 14 Harv CR-CL L Rev 485, 50813 (1979).

${ }^{89}$ See Zykan $v$ Warsaw Community School Corp., 631 F2d 1300 (7th Cir 1980). This is the plurality's approach in Pico and has been used by some lower courts. In Loewen $v$ Turnipseed, 488 F Supp 1138 (N D Miss 1980), the state textbook selection committee failed to accept a textbook describing the civil rights movement in Mississippi. The plaintiffs (a group of parents, students, authors, and publishers) filed suit, claiming that the committee's decision was racially motivated and that the procedures were unconstitutional. Id at 1152,1154 . The plaintiffs also charged that the books the schools used championed white supremacy and portrayed blacks negatively. Fitzgerald, America Revised at 29 (cited in note 2). The district court agreed that the decision was racially motivated and thus infringed the plaintiffs' First Amendment rights. Loewen, $488 \mathrm{~F}$ Supp at $1149,1151,1154$. For a discussion of school board motives, see Lichtenstein, 19 USF L Rev at 129-137 (cited in note 85).

${ }^{80}$ The Second Circuit adopted this position in President's Council, District 25 v Community School Board No. 25, 457 F2d 289 (2d Cir 1972). Plaintiff children, parents, and teachers challenged a school board decision restricting the use of a certain book. Id at 290 . The court stated that judicial interference should occur only in "rare and extreme" circumstances, such as where a school board decision goes so far as to interfere with the actual free speech activities of students. Id at 292. Moreover, the court held that the school board had the discretion to remove books "for whatever reason," id at 292-3. See also Epperson v Arkansas, 393 US 97, 112-13 (1968) (Black concurring) (state is free to choose its curriculum).

${ }^{91}$ See, for example, Keyishian $v$ Board of Regents, 385 US 589, 603 (1967) (First Amendment "does not tolerate laws that cast a pall of orthodoxy over the classroom"). See also Board of Education v Barnette, 319 US 624, 642 (1942). 
icated upon a traditional concern for the interests of religious and nonreligious minorities. In Justice O'Connor's words, the Establishment Clause prevents the state from communicating to minorities the message that they are religious "outsiders, not full members of the political community ...." Th2 This concern for minorities is particularly important in the public school context because of the socialization process inherent in education. ${ }^{93}$

The Supreme Court has expressed this notion of minority protection through the concept of majoritarian coercion. As interpreted, the primary concern of the Establishment Clause is preventing state coercion of religious choice:

The Establishment Clause, unlike the Free Exercise Clause, does not depend upon any showing of direct governmental compulsion and is violated by the enactment of laws which establish an official religion, whether those laws operate directly to coerce non-observing individuals or not. ... When the power, prestige, and financial support of government is placed behind a particular religious belief, the indirect coercive pressure upon religious minorities to conform to the prevailing officially approved religion is plain. ${ }^{94}$

22 Justice O'Connor has attempted to rest the constitutionality of state action upon the transmission of such a message. See Lynch $v$ Donnelly, 465 US 668, 687-88 (1984) (O'Connor concurring). O'Connor's test was recognized by the full court in Wallace $v$ Jaffree, 472 US 38, 56 n 42 (1984).

${ }^{23}$ See McCollum 0 Board of Education, 333 US 203, 227-28 (1948) (Frankfurter concurring):

The children belonging to these non-participating sects will thus have inculcated in them a feeling of separation when the school should be a training ground for habits of community, or they will have a religious instruction in a faith which is not that of their parents. As a result, the public school system ... sharpens the consciousness of religious differences at least among the children committed to its care.

'4 Engel v Vitale, 370 US 421, 430-31 (1962). See also Grand Rapids School District v Ball, 473 US 373, 389 (1985) ("Government promotes religion as effectively when it fosters a close identification of its powers and responsibilities with those of any, or all, religious denominations as when it attempts to inculcated specific religious doctrines.") This concern for the freedom to choose beliefs is seen by commentators as central to the Court's jurisprudence. See Philip B. Kurland, Religion and the Constitution, 20 UC Davis L Rev 705, 717 (1987) (preserving the "freedom of the individual mind" is reason behind the First Amendment, including the religion clauses). See also Gail Merel, The Protection of Individual Choice: A Consistent Understanding of Religion Under the First Amendment, $45 \mathrm{U}$ Chi L Rev 805, 806 (1978); Jesse Choper, The Religion Clauses of the First Amendment, $41 \mathrm{U}$ Pitt L Rev 673, 675 (1980); Alan Schwarz, No Imposition of Religion: The Establishment Clause Value, 77 Yale L J 692, 728 (1968). This appears to be the popular understanding as well. See Amy Gutmann, Principals, Principles, New Republic 32, 35-36 (Dec 12, 1988) ("Liberals" oppose voluntary school prayer due to concern over "pressure" to conform). For the view that government action does not violate the Establishment Clause unless it actually coerces religious choice, see Michael W. McConnell, Coercion: The Lost Element of Estab- 
To prevent the indirect religious coercion that flows from establishments, the Court requires the state to maintain a stance of "neutrality" between religion and non-religion. Defining neutrality has not been an easy task, however, and the Court has struggled to create an institutional arrangement between the state and religion that does not in fact coerce religious belief.

The initial attempt to define neutrality came in Everson $v$ Board of Education. ${ }^{98}$ There, Justice Black wrote for the majority that the wall between church and state must be kept high and impregnable. 97 This "strict separation" standard, based upon a broad construction of the Establishment Clause, appeared to bar all government involvement with specific religious groups and with religion in general. ${ }^{98}$ It proved to be a powerful tool in removing religious influence from the public schools.

In $M$ cCollum $v$ Board of Education, ${ }^{99}$ the Court struck down a "released time" program that permitted religious teachers to come into public schools on a weekly basis and teach voluntary religious classes during school hours. ${ }^{100}$ The Court used a basic secular/religious dichotomy as a starting point from which to judge the constitutionality of value inculcation. Under this standard, courses determined to be forms of religious indoctrination would be barred from the schools. ${ }^{101}$ The Court has also rejected individual activities led by school officials, holding that the prayer recitation ${ }^{102}$ and

lishment, $27 \mathrm{Wm} \&$ Mary L Rev 933, 939-40 (1986). In addition to protecting religious choice, the Establishment Clause is also concerned with preventing sectarian strife and protecting the autonomy of religion. Engel, 370 US at 431-32.

${ }^{88}$ Abington School District v Schempp, 374 US 203, 226 (1963) ("In the relationship between man and religion, the state is firmly committed to a position of neutrality.") See also Jaffree, 472 US at $52-53 \mathrm{n} 37$.

${ }^{98} 330$ US I (1947). In Everson, the Court upheld a New Jersey program that reimbursed parents for the cost of sending their children to Catholic schools via public transportation.

${ }^{97}$ Id at 18. This standard was derived in part from Jefferson's famous "wall of separation." Id at 16, quoting Reynolds v US, 98 US 145, 164 (1878).

${ }^{98}$ The Court also stated that the clause bars all aid to religion. Everson, 330 US at 16.

${ }^{89} 333$ US 203 (1948).

100 Justice Black, writing for the Court, held that this was "beyond all question a utilization of the tax-established and tax-supported public school system to aid religious groups to spread their faith. And it falls squarely under the ban of the First Amendment ...." Id at 210 .

${ }^{101}$ It is not immediately clear whether $\mathrm{McCollum}$ is predicated directly upon a concern over the coercion of public school students (see Justice Frankfurter's concurrence, 333 US at 227-28) or upon a concern over the use of school property by private religious groups. In Zorach $v$ Clauson, the Court approved a released time program conducted off school grounds. 343 US 306, 315 (1952).

${ }^{102}$ Engel, 370 US at 421. 
Bible reading ${ }^{103}$ in public school classrooms is unconstitutional. In Epperson v Arkansas, ${ }^{104}$ the Court struck down an Arkansas statute that prohibited the teaching of evolution because "fundamentalist sectarian conviction was and is the law's reason for existence." 105

The Court began to move away from strict separation in Board of Education $v$ Allen ${ }^{108}$ when it approved a mandatory textbook loan program that benefitted parochial schools. In Lemon $v$ Kurtzman, ${ }^{107}$ the Court reached the conclusion that "total separation [was] not possible,"108 and proceeded to lay down the test it still uses to judge Establishment Clause challenges:

First, [a] statute must have a secular legislative purpose; second, its principle or primary effect must be one that neither advances nor inhibits religion ... .; finally, the statute must not foster 'an excessive government entanglement with religion.'

In Lemon, the court used the entanglement prong ${ }^{110}$ to invalidate salary supplements to teachers of secular subjects in private schools. ${ }^{111}$

In subsequent applications of the Lemon test, the court has tried to avoid categorical approaches to the accommodation of religion in the modern state. ${ }^{112}$ As a result, the court has reached vary-

10s Schempp, 374 US at 226.

104393 US 97 (1968).

${ }^{105}$ Id at 107-08. The Court explained: "The state's undoubted right to prescribe the curriculum for its public schools does not carry with it the right to prohibit, on pain of criminal penalty, the teaching of a scientific theory or doctrine where that prohibition is based upon reasons that violate the First Amendment." Id at 107.

${ }^{108} 392$ US 236 (1968).

107403 US 602 (1971).

${ }^{108}$ Id at 614. As Chief Justice Burger expressed "Candor compels acknowledgement ... that we can only dimly perceive the lines of demarcation in this extraordinarily sensitive area of constitutional law ... . The language of the Religion Clauses ... is at best opaque . . . ." Id at 612 .

109 Id at 612-13 (citation omitted).

${ }^{110}$ The entanglement test originated in Walz $v$ Tax Commission, 397 US 664, 674 (1970).

"11 Lemon, 403 US at 625.

112 Mere accommodation does not violate the Establishment Clause even if it goes beyond that mandated by the Free Exercise Clause, although at some point accommodation can become establishment. See Corporation of the Presiding Bishops v Amos, 483 US 327, $107 \mathrm{~S} \mathrm{Ct} 2862,2867$ (1987). The Court has indicated that accommodation may sometimes be required. See Lynch, 465 US at 673 (Constitution "affirmatively mandates accommodation, not merely tolerance, of all religions"); Zorach, 343 US at 314 (to forbid accommodation would "show a callous indifference to religious groups. That would be preferring those who believe in no religion over those who believe."). 
ing outcomes in cases dealing with aid to private schools. ${ }^{113} \mathrm{De}$ spite this flexibility, the Court remains "particularly vigilant" in scrutinizing religious influences in public schools, ${ }^{114}$ relying on Lemon in nearly every school- related case. ${ }^{115}$

One indication of this vigilance is the Court's intense scrutiny of legislative purpose. ${ }^{116}$ For example, in Stone $v$ Graham, ${ }^{117}$ the Court struck down a Kentucky statute that required the posting of the Ten Commandments, finding that the statute had a predominate purpose that was "plainly religious in nature."118 The trial court had, by contrast, found the "avowed" purpose was secular. ${ }^{118}$ The Supreme Court reasoned that since posting the Ten Commandments did not serve an educational purpose, the only effect was to induce school children to "read, meditate upon, and perhaps to venerate and obey, the Commandments."120 Likewise, in Wallace $v$ Jaffree, the Court struck down a "moment of silence" law by finding a religious motive in the legislative history. ${ }^{121}$ In $E d$ -

${ }^{113}$ See Committee for Public Education v Nyquist, 413 US 756 (1973) (tuition reimbursement grants and income tax benefits to parents whose children attend sectarian schools impermissibly advance religion); Mueller v Allen, 463 US 388 (1983) (state tax deduction for expenses in sending child to parochial schools does not violate Establishment Clause); Commission for Public Education v Regan, 444 US 646 (1980) (state reimbursement to all private schools for costs of complying with state testing and record keeping requirements does not violate Establishment Clause); Wolman v Walter, 433 US 229 (1977) (state funding to provide nonpublic school students with books, standardized testing and diagnostic and remedial services is constitutional; funding for instructional materials and field trip services is unconstitutional); Roemer $v$ Bd. of Public Works of Maryland, 426 US 736 (1976) (state subsidy to private colleges for exclusively non-sectarian purposes is constitutional).

${ }^{114}$ Edwards $v$ Aguillard, 482 US 578, 107 S Ct 2573, 2577 (1987). The primary concern is coercion of young and impressionable students. Id. See also McCollum, 333 US at 227 ("The law of imitation operates, and non-conformity is not an outstanding characteristic of children.") Contrast, for instance, the failure to find constitutional violations in cases dealing with colleges and universities. Widmar $v$ Vincent, 454 US 263, $274 \mathrm{n} 14$ (1981); Tilton $v$ Richardson, 403 US 672, 685-86 (1971). See also Marsh v Chambers, 463 US 783, 792 (1982) (adults not subject to "peer pressure").

${ }^{125} \mathrm{Ball}, 473$ US at 383 . The Court has occasionally decided non-school cases without Lemon. See Marsh, 463 US 783 (legislative chaplains do not violate the Establishment Clause).

${ }^{116}$ Justice Scalia has criticized the use of the purpose prong, arguing that it is impossible for the court to determine legislative purpose. See his dissent in Aguillard, $107 \mathrm{~S} \mathrm{Ct}$ at 2605-07.

117449 US 39 (1980).

118 Id at 41.

119 Id. The legislature attempted to attach a secular purpose onto the statute by requiring the copies of the Ten Commandments to mention their incorporation into Western law. Id.

120 Id at 42. The Court distinguished a school's use of the commandments in a comparative religion class, where an educational purpose would exist. Id.

121472 US 38, 56-61 (1985). 
wards $v$ Aguillard, the Court found that a Louisiana statute requiring the teaching of creation science in public schools had no secular purpose and was in fact specifically meant to promote a religious viewpoint. ${ }^{122}$

Given the Court's concern with indoctrination, the propriety of including certain items in the classroom is dependent upon their mode of presentation. ${ }^{123}$ The Court has often noted that the effect prong of the Lemon test would not bar reading the Bible objectively, in a non-indoctrinating manner, as in the context of a comparative religion class. ${ }^{124}$

The Court does not require a showing of actual coercion to support a constitutional claim, but rather infers religious coercion when it discovers an establishment. ${ }^{125}$ Thus, mere exposure to an establishment is sufficient, whether it be a "moment of silence," voluntary scripture reading, or posting of the Ten Commandments. The Establishment Clause thus sets absolute standards by which to judge the propriety of activities carried on within the schools. ${ }^{126}$

The state is restricted not only from endorsing a particular sect or religious viewpoint but from providing any support for religious belief in general. This broad reading necessarily requires a corresponding protection for religion when the government fosters an anti-religious bias, either through the establishment of a religion of secularism ${ }^{127}$ or the disparagement of religion. ${ }^{128}$ The Court

122482 US 578, $107 \mathrm{~S} \mathrm{Ct} .2573,2578-81$ (1987). In the Court's view, the act was designed either to promote "creation science which embodies a particular religious tenet . . . or to prohibit the teaching of a scientific theory disfavored by certain religious sects by forbidding the teaching of evolution when creation science is not also taught. The Establishment Clause, however, 'forbids alike the preference of a religious doctrine or the prohibition of a theory which is deemed antagonistic to a particular dogma.' "Id at 2582 (emphasis in original), quoting Epperson, 393 US at 106-07.

${ }_{123}$ Yudof, 57 Tex L Rev at $875 \mathrm{n} 44$ (cited in note 58), citing Schempp, 374 US at 225.

124 Schempp, 374 US at 225, 306 (Goldberg concurring); Stone, 449 US at 42; Epperson, 393 US at 106.

125 Grand Rapids v Ball, 473 US 373, 385-92 (1985) (concern over "potential" harm); McGowan v Maryland, 366 US 420, 429-30 (1961); Brandon v Board of Education of the Guilderland Central School District, 635 F2d 971, 978 (2d Cir 1980); Strossen, 47 Ohio St L $\mathrm{J}$ at 363 (cited in note 63). While these cases do not explicitly say that no finding of coercion is required, they identify violations of the Establishment Clause without articulating how the coercion operated.

${ }^{128}$ Unlike the restrictions derived from the Free Exercise Clause, which apply to schools depending upon the nature of the students who attend, the Establishment Clause sets absolute standards by which to judge the propriety of educational programs. The exemption of particular students does not save an Establishment Clause violation. Schempp, 374 US at 224-25; Engel, 370 US at 430-31. Censorship is the only remedy when an Establishment Clause violation is found.

${ }^{127}$ Schempp, 374 US at 225 (state cannot establish "secularism" in the sense of "affirmatively opposing or showing hostility to religion"). 
recognized this in the Lemon test's second prong that a law's principal or primary effect "be one that neither advances nor inhibits religion." $12 \theta$

Thus, in addition to protecting minorities from majoritarian coercion, the inhibition prong of the Establishment Clause carves out a realm of existence for religion that is separate and distinct from the state. The republican tradition recognizes that there can be independent and autonomous sources of the "public good" outside of the individual or the state. ${ }^{130}$ The Establishment Clause, interpreted as a non-individualistic ${ }^{131}$ provision, responds to this tradition by prohibiting government from "inhibiting" religion. This proscription also acts as a buffer against totalitarianism because it protects at least a small aspect of life from state coercion. Recent recognition of the importance of religion to the vitality of a democratic state emphasizes the continued value of protecting not only the state from religion but religion from the state. ${ }^{132}$ As Justice Brennan has noted, religion "uniquely contribute[s] to the pluralism of American society ....."133

The inhibition prong acts then as a free exercise component of the Establishment Clause. In Justice Brennan's words, the prong prevents the Establishment Clause from being used "as a sword to justify repression of religion . . . from any aspect of public life."134 Presumably, then, the same degree of protection that prevents the state from promoting religion should apply to prevent it from in-

128 " The government is neutral, and while protecting all, it prefers none, and it disparages none." 'Schempp, 374 US at 215, quoting Minor $v$ Board of Education of Cincinnati, an unpublished Ohio Superior Court opinion from 1870 (emphasis in original). See also Everson, 330 US at 18 (state power cannot be used to "handicap" religion); Braunfeld $v$ Brown, 366 US 599, 607 (1961) (state cannot "impede the observance of one or all religions"); Epperson, 393 US at 104 (government may not be "hostile to any religion"); Aguilar $v$ Felton, 473 US 402, 414 (1985) (government may not hinder any particular faith or faith generally).

${ }^{128}$ Lemon, 403 US at 612-13 (emphasis added).

${ }^{130}$ See, for example, Robert N. Bellah, et al, Habits of the Heart at 252-56 (Perennial Library, 1985); Arons, Compelling Belief at 195 (quoting John Stuart Mill) (cited in note 3).

${ }^{131}$ See Mark Tushnet, The Constitution of Religion, 18 Conn L Rev 701, 735-38 (1986). The non-individualistic interpretation of the Establishment Clause contrasts with the liberal tradition which rejects intermediate institutions between the state and the individual. Id at $730-35$.

${ }^{132}$ See Allan Bloom, The Closing of the American Mind at 194-99 (Simon \& Schuster, 1987); Dent, $61 \mathrm{~S} \mathrm{Cal} \mathrm{L} \mathrm{Rev} \mathrm{at} 875$ (cited in note 3) (Framers saw the importance of religion); Richard J. Neuhaus, The Naked Public Square (Eerdmans, 1984); Bellah, Habits of the Heart at 219-227 (cited in 130); This recognition of religion's role is not new. See Alexis de Tocqueville, 1 Democracy in America at 314-326 (Vintage, 1945).

${ }^{133}$ Walz v Tax Commissioner, 397 US 664, 689 (1970) (Brennan concurring).

134 McDaniel v Paty, 435 US 618, 641 (1978) (Brennan concurring). 
hibiting religion, since both are forms of religious coercion.

\section{The Problem With Neutrality}

As discussed in section II, the Supreme Court has not reached a consensus on whether freedom of speech concerns place any direct limits on the power of the government to inculcate particular values. But as section III indicates, the Court has recognized that the Establishment Clause places strict substantive restraints on what the state may say and thereby propagate through the public school system. Teaching methods and materials used in the curriculum must be neutral toward religion both in purpose and effect. ${ }^{135}$ The Court's quest for neutrality in the curriculum context is largely illusory, however, as it is not clear that any choice of curriculum programs can pass either the purpose or effect hurdles, much less both.

The initial difficulty lies in positing a set of principles that are "neutral" toward religion. ${ }^{136}$ In theory, neutral values that reflect this constitutional norm can be freely inculcated in the schools; values that conflict with this norm are unconstitutional. As attractive as this theory may be, however, defining these values is not easy. It is not surprising that the Supreme Court has shrunk from the task. What it has done in its series of opinions is define certain practices as non-neutral. For instance, neutrality is violated when the schools teach sectarian values ${ }^{137}$ or, at the other extreme, when they teach "secularism," defined as hostility to religion. ${ }^{138}$ The mere exclusion of these teachings, however, provides little guidance as to the nature of a truly neutral curriculum.

What would neutral values look like? Some commentators have tried to delineate preeminent "democratic" values that should be imposed on all students. ${ }^{133}$ But even if certain core

135 There is a potential entanglement problem whenever the courts make pronouncements on moral and philosophical issues such as this. Proscribing that which is religious requires defining religion, and that is a very difficult task. See, for example, United State $v$ Ballard, 322 US 78, 86 (1944) (First Amendment forbids inquiry into veracity of religious beliefs). See also Dent, $61 \mathrm{~S}$ Cal L Rev at 910 (cited in note 3).

${ }^{138}$ For a judicial discussion of the need to distinguish "non-religious" government action in the education context, see Judge Canby's concurring opinion in Grove $v$ Mead School Dist No 354, 753 F2d 1528, 1536-37 (9th Cir 1985). For commentary, see Stanley Ingber, Religion or Ideology: A Needed Clarification of the Religion Clauses, 41 Stan L Rev 233,310 (1989) (arguing that the courts should recognize a distinction between "irreligion" and "non-religion"); Merel, $45 \mathrm{U}$ Chi L Rev at 813 (cited in note 94).

${ }^{137} \mathrm{McC}$ Collum, 333 US at 211-12.

${ }_{138}$ Schempp, 374 US at 225.

130 Gutmann, Democratic Education at $44-45$ (cited in note 48) (non-repression and 
norms are identified, it is doubtful that they can be non-controversially translated into more specific value judgments. ${ }^{140}$ Freedom may be a basic democratic value, but does that mean that one would be free to challenge authority or not join the military? Most people will probably agree that a national consensus upon specific values is no longer possible, if indeed it ever was. ${ }^{141}$ There is simply no neutral "baseline" by which to judge the proper values to be taught in the schools. Thus, any values that are adopted by the schools will result in the imposition of one group's values upon another group.

Take, for example, the ideas in the contested home economics books in Smith that values are "personal and subjective." The district court found that this assumption was "based on a particular vision of human nature unrelated to science"142 and hence represented a non-neutral philosophy of secular humanism. The Eleventh Circuit considered the values taught in the textbooks "entirely appropriate" and found any parallel to secular humanism insufficient to render them unconstitutional. ${ }^{143}$

But in what way can the belief that morality is a personal choice be considered neutral? At some level, it is surely a rejection of the proposition advanced by the plaintiffs in Smith that values can also be derived from divine command. If one believes in a divinely inspired morality, the textbooks in Smith transmit more than a subtle state "message" of non-endorsement. How can this non-endorsement be neutral when it would almost surely not be neutral to inculcate that moral norms come from God ${ }^{144}$ Even if

non-discrimination as two examples of democratic values); Strossen, 47 Ohio St L J at 37577 (cited in note 63) (two preeminent values are tolerance for a diversity of viewpoints, religious, political and otherwise, and belief in equal rights and opportunities).

${ }_{140}$ Dent, $61 \mathrm{~S}$ Cal L Rev at 910 (cited in note 3)(discussing the implications of the ERA battle).

${ }^{141}$ Robert D. Kamenshine, The First Amendment's Implied Political Establishment Clause, 67 Cal L Rev 1104, 1134 (1979) (U.S. has no "uniformly acceptable" values). See also Dent, $61 \mathrm{~S}$ Cal $\mathrm{L}$ Rev at 910 (cited in note 3).

142 Sith, 655 F Supp at 986 ,

143 Smith, 827 F2d at 692.

${ }^{144}$ All curricular programs reflect certain asiuptions about the nature of the universe and humankind. See Purpel and Ryan, Moral Education at 57 (cited in note 48). A personal approach to value formation as applied through a consistent curricular program is not in itself value free and does not pretend to be. Id at 122. "Values Clarification," a moral education program used by hundreds of schools, consciously reflects moral subjectivism. See Simon, Howe and Kirschenbaum, Values Clarification at 15-22 (cited in note 12). See also Gutmann, Democratic Education at 56 (cited in note 48) and Alan Freeman and Betty Mensch, Religion as Science/Science as Religion, 2 Tikkun 64, 67 (Nov/Dec 1987) (prevailing ideology in public schools reflects a certain view of reality). Many religious groups doctrinally reject a personal approach to value formation. See Note, The Establishment Clause, 
secular humanism is not a religious belief system, ${ }^{145}$ courts are on tenuous grounds in choosing a relativistic value system as the only constitutional norm that can be established by the state in its curriculum. The state cannot prove the ultimate truth of relativism any more than it could have proven the validity of the Protestant ideology once embraced by the public schools. The fact that a relativistic approach does not coincide with a recognized religious approach to value formation does not make it true, nor does it make it neutral under the Establishment Clause.

Neutrality itself is a faulty concept. The search for a non-religious ideology, as opposed to one that neither promotes nor inhibits religion, is a fanciful search for the non-existent. Individuals assert the validity of their different claims to truth not on the ground that their claims are non-religious but on the ground that they are true. Thus, when textbook authors choose to enshrine a personal approach to value formation they do so not because it is non-religious but because they consider such an approach true and thus worthwhile for children to learn. ${ }^{146}$ The neutrality of any such claim to truth rests solely upon perspective. A relativistic approach may seem neutral to the relativist, but it will not seem neutral to the absolutist. Establishments are prohibited precisely because the state should not determine whose truth reflects reality, particularly on matters that fall within the realm of conscience. ${ }^{147}$

Some argue that a personal approach to value formation is the

Secondary Religious Effects, and Humanist Education, 91 Yale L J 1196, 1208-09 (1982). It is certainly difficult to argue that the subjective approach to values embraced by the Eleventh Circuit in Smith is rooted in American history. Indeed, the contrary appears more accurate.

145 The Supreme Court has indicated in dictum that "secular humanism" may be a religious belief system. See Torcaso $v$ Watkins, 367 US 488, 495 n 11 (1961). Some secular humanism is clearly anti-religious in nature. Ingber, 41 Stan L Rev at 318 (cited in note 136). The Humanist Manifesto II begins:

We find insufficient evidence for belief in the existence of the supernatural; it is either meaningless or irrelevant to the question of the survival and fulfillment of the human race. As non-theists we begin with humans, not God, nature, not deity. We can discover no divine purpose or providence for the human species. While there is much we do not know, humans are responsible for what we are or will become. No deity will save us; we must save ourselves.

Humanist Manifesto II, quoted in Vitz, Censorship 102-03 (cited in note 10).

It is interesting to note, as the trial court in Smith did, that John Dewey, the father of modern education, signed the Humanist Manifesto I. Smith, 655 F Supp at 994.

${ }^{116}$ It would be absurd to force children to learn a doctrine that no one considers true just because it happens to fall into a hypothetical category that is neither religious nor antireligious.

${ }^{147}$ See Schempp, 374 US at 226. 
neutral theory which informs the First Amendment ${ }^{148}$ and is simply non-religious as opposed to being religious or anti-religious in nature. But does it then follow that the imposition of this neutral value should trump the protections of the religion clauses if its imposition has the "effect" of inhibiting religion? It may be proper for government to espouse certain values in certain contexts, but it is not obvious that it can do so in the coercive environment of a public school classroom without violating the mandate of Lemon that government not act to inhibit religion. ${ }^{149}$

The Eleventh Circuit, after asserting that the values expressed in the textbooks in Smith were "neutral," reasoned that "neutrality" by definition does not inhibit religion. The court found authority for this proposition only in the language of $\mathrm{McCollum}$ and Engel. ${ }^{150}$ But the language cited by the court in these two cases indicates merely that excluding non-neutral items, such as sectarian instruction ${ }^{151}$ and prayer, ${ }^{152}$ cannot be considered hostile to religion. The court reasons purely by negative inference that anything left in the schools thereby is neutral in effect, either as to religious or non-religious students.

There is at best a subtle distinction between anti-religious and non-religious ideologies, particularly for a religious, school-age child. Impressionable students will have a very hard time distinguishing between statements that are hostile to their religion and those that are merely inconsistent with it. ${ }^{153}$ The Supreme Court has recognized this in striking down school prayers and Bible readings. Yet, there is no functional distinction between forcing children to learn doctrines directly inconsistent with their religious beliefs and, for example, forcing a Jewish child to read from the New

\footnotetext{
${ }^{148}$ In Smith, the state argued that if the textbooks did represent a religion, it was a religion established by the Constitution itself. 655 F Supp at 948 .

${ }_{140}$ Many forms of government action are impermissible in the public school setting but not in others. For instance, even voluntary prayer is unconstitutional in the public schools. Engel, 370 US at 436. However, in other contexts, such as the military or prisons, government may even be required to subsidize religious activity. See note 63 .

${ }^{130}$ Smith, 827 F2d at 692.

$161 \mathrm{McCollum}, 333$ US at 211-12.

${ }^{162}$ Engel, 370 US at 433-35.

${ }^{263}$ See Dent, $61 \mathrm{~S}$ Cal L Rev at 892 (cited in note 3). It seems questionable to presume that school age children can understand fine philosophical distinctions when the courts have already held: that students cannot recognize that voluntary religious groups receiving the same treatment as other student groups do not have the support of the state, see Bender $v$ Williamsport Area School District, 741 F2d 538, 552 (3d Cir 1984), rev'd on other grounds, 475 US 534 (1986); and that parochial school students cannot distinguish between religious classes taught by parochial school employees and secular classes taught by public employees, Ball, 473 US at 392 .
} 
Testament. If anything, the impact of offensive doctrines may be greater than the impact of voluntary prayer on non-religious students. Many non-religious doctrines attack the core beliefs of religious students, ${ }^{154}$ beliefs that, when expressed by students in the Court's "neutral" world, may receive "unsatisfactory" grades. ${ }^{105}$

At a minimum, when the state adopts the message of the home economics books in Smith that values are personal and subjective, ${ }^{166}$ it signals to conservative Christian children that they are "outsiders." Requiring the children to ignore this message is inconsistent with the Court's treatment of exposure to voluntary religious activities. Although some of the concerns of religious students may be addressed by the Free Exercise Clause, ${ }^{157}$ to the extent that Establishment Clause jurisprudence is concerned with coercion it should be cognizant of all forms of interference with religious choice.

\section{The Proposal}

\section{A. The Establishment Clause Prohibition}

In light of the inevitably non-neutral nature of curriculum decisions, this comment proposes a test to evaluate and hopefully minimize the coercive effect that curriculum choices can have on both religious and non-religious students. Courts should find establishments whenever a school board makes a pattern of choices about the curriculum that either (a) directly promotes or disparages a religious viewpoint or (b) presents an exclusive view of an inherently religious issue. Although this test abandons the illusive

${ }^{154}$ Gregory Gelfand, Of Monkeys and Men - An Atheist's Heretical View of the Constitutionality of Teaching the Disproof of a Religion in the Public Schools, 16 J L \& Educ 271, 308 (1987) (teaching evolution destroys the core beliefs of fundamentalists).

${ }^{185}$ Freeman and Mensch, 2 Tikkun at 65 (cited in note 144). Requiring students to make statements on tests that completely undermine those students' religious upbringing might very well constitute coerced speech. See Wooley v Maynard, 430 US 705, 713-17 (1977) (Court finds that forced use of private property to support a particular type of speech violates the First Amendment).

${ }^{256}$ Professor Strossen has suggested that secular humanism may possibly survive constitutional scrutiny because it involves analytical discussion as opposed to the devotional nature of the practices involved in the Court's decisions. 47 Ohio St L J at 358 (cited in note 63). An analytical discussion, of course, can help to prevent indoctrination. However when the state adopts an exclusive position on an issue the message of state promotion is clear. An analytical discussion of scripture in a moral education class would hardly survive constitutional scrutiny if scripture was all that was discussed. Moreover, the analytical methodology of some programs may reflect an ideology as well.

${ }_{157}$ See generally Dent, $61 \mathrm{~S} \mathrm{Cal} \mathrm{L} \mathrm{Rev} \mathrm{at} \mathrm{880-901} \mathrm{(cited} \mathrm{in} \mathrm{note} \mathrm{3)} \mathrm{and} \mathrm{Strossen,} 47$ Ohio St L J at 385-96 (cited in note 63) for a discussion of potential free exercise claims. 
neutrality contemplated in Lemon, it creates a constitutional norm by which individuals are as free of religious coercion as is feasible within the inherently coercive public school environment.

The test applies only to educational materials that reflect school policy and therefore establish a governmental message on a religious issue. Textbooks will almost always reflect school policy; library books will not, unless there is some discernably coercive pattern to book acquisition.

The requirement of a pattern ensures that only substantial, long term practices are vulnerable to challenge. An objective observer should be able to discern a governmental message from the pattern. The mere fact that a teacher or textbook departs from the norm on occasion is not sufficient to raise constitutional questions, unless, of course, a religious motive is present. A pattern will be found if a school systematically presents an issue in a way that promotes or disparages religion or presents an exclusive view of a religious issue. For instance, the mere inclusion of a controversial book or novel in a curriculum ${ }^{158}$ will rarely establish a pattern unless it is part of a broader selection of books that taken as a whole present a government message. However, if one textbook is the sole source of discussion on an issue, a pattern should be inferred.

\section{Direct promotion or disparagement.}

To be subject to this restriction, a viewpoint must be reasonably identified with a group or groups recognized as religious (Catholics, Christian Scientists) or with a group defined primarily by a recognized religious position (atheists). ${ }^{\mathbf{1 6 9}}$ Discussion of facts or values not identified with a group but merely consistent or inconsistent with a religious position will not generally be considered promotion or disparagement. In addition, the teaching of demonstrably objective facts, that is, facts that the courts are prepared to declare as truth, ${ }^{160}$. should provide a defense to a charge of promotion or disparagement.

In determining what values a school can consciously promote in its curriculum, a starting point should be those values that the

${ }^{158}$ Strossen, 47 Ohio St L J at 381-82 (cited in note 63).

158 The first part of this test is similar to tests developed in other articles. See Kamenshine, 67 Cal L Rev at 1115-19 (cited in note 141) (only political speech by a governmental institution is unconstitutional).

${ }^{180}$ The Religion Clauses prevent the courts from declaring the veracity of religious tenets. United States $v$ Ballard, 322 US 78, 86 (1944). Thus, only facts that do not implicate religious doctrine should provide a state with such a defense. 
state has decided to enforce through law. Thus, a school can teach that stealing and discrimination, at least in certain contexts, are wrong. However, there are religious areas of life that are protected from state influence ${ }^{\mathbf{1 6 I}}$ and a school's curriculum should reflect this protection.

Obviously, a school can teach that "murder is wrong." The mere fact that this value coincides with Biblical commands does not violate the Establishment Clause. Since laws have moral content, they inculcate values to a certain extent. No one would suggest striking down laws forbidding homicide merely because the laws convey a message that killing is "wrong." An Establishment Clause violation would occur, however, if a school states that "murder is wrong because it violates the Ten Commandments." This directly promotes a religious viewpoint-that moral norms come from the Bible-associated with religious groups (in this case, Jews and Christians).

Disparagement is more difficult to detect, but can be defined as a direct unrebutted attack upon or ridicule of a religious viewpoint. ${ }^{162}$ Attacks upon any group defined by a religious perspective should not be permissible in the context of a religious discussion. The primary concern is that no direct challenge be made to any specific religious belief or to religion in general.

For instance, it is acceptable for a school to teach that discrimination, as a general matter, is wrong. This, of course, is the law and the state should be able to promote this viewpoint regardless of whether it offends specific beliefs. However, if the school maintains that one particular church's failure to ordain women is backward, this is disparagement because the church has been singled out for negative treatment.

Omission can promote or disparage religion even though the school does not identify religion or religious groups specifically. Omitting religious references has an impact on religion generally, and although it does not affect any one sect or denomination in the same way that direct disparagement would, completely ignoring religion is impermissible to the extent that it portrays religion as irrelevant. ${ }^{183}$ Blatant marginalization of religion is disparagement of

161 See, for instance, Title VII \$702, 42 USC \$2000e-1 (1987), which exempts religious organizations from anti-discrimination laws.

162 Thus, this restriction should prohibit those exercises in values education programs that directly disparage religious ideas, such as the following question: "How many of you ... would choose to die and go to heaven if it meant playing a harp all day?" Simon, Howe, and Kirschenbaum, Values Clarification at $41-43$ (cited in note 12).

${ }^{163}$ The invisibility of a group is a statement in itself. One report on curricular treat- 
religion. ${ }^{164}$

Judicial review in the context of omission is difficult because the line between poorly written textbooks and outright disparagement or promotion of religion can be very thin. Judicial review of omissions may also eviscerate local school board discretion. These concerns over judicial review coupled with the less direct impact of omission upon religious choice should lead the courts to defer to school board decisions in the absence of evidence that, in choosing certain textbooks, the board had a specific motive or purpose to promote or disparage religion. In other words, cases of omission should depend on the Lemon test's purpose prong inquiry. If a factual distortion or omission is so severe that an educated objective observer could infer a disparaging motive in the choice of those particular texts, then there is an Establishment Clause violation. ${ }^{165}$

\section{Inherently religious areas.}

In addition to prohibiting direct promotion or disparagement of specific religions or religion as a whole, the proposed test prohibits schools from teaching an exclusive viewpoint in an inherently religious area. If curricula address these troublesome areas at all, they must provide a balanced presentation. As difficult as the task may be, it is necessary to identify inherently religious areas. Religious choice can only be protected in the context of a compul-

ment of women and minority groups argues that the invisibility of "women and minority groups has become so great as to imply that these groups are of less value [and] importance ...."Vitz, Censorship at 100 (cited in note 10).

There is an egregious omission of religious references in primary and secondary school textbooks. For instance, a recent study examining 60 social studies texts found not one word concerning any aspect of religious activity in American life. An examination of 670 history stories found that none featured Christian or Jewish religious motivation. Vitz, Censorship at 3 (cited in note 10 ). In a study of basic readers, $72 \%$ completely failed "a minimum test with respect to reference to God, Christianity, or Judaism." Id at 70. One social studies book included a thirty page discussion of the Pilgrims without mentioning any aspect of their religious faith. Id at 3. Many texts do not even mention the role of religion in the life of Martin Luther King, Jr. Id at 49. In addition to being incomplete historically, these textbooks are anti-religious in the same sense that prior textbooks were racist.

164 There is little reason to assume that the selection of textbooks is based on specific motives of local educators to omit religious references. Vitz, Censorship at 1,80 (cited in note 10). More likely, such omissions result from the secular mind-set of the upper echelons of the education establishment and from deliberate censorship of religious concepts and vocabulary by publishers. Id at 79 .

${ }^{185}$ The Court has inferred these kind of motives before. See Stone $v$ Graham, 449 US 39, 42 (1980) (posting the Ten Commandments could not have an educational purpose); Aguillard v Edwards, 482 US 578, $107 \mathrm{~S} \mathrm{Ct} 2573$ (1987) (requirement that creation science be taught is religiously motivated). If the motives of state legislators can be inferred in Stone and Aguillard, the motives of textbook purchasers should be relevant as well. 
sory education system monopolized by the state if some area is carved out of the curriculum and insulated from state indoctrination.

Two possible standards can be used to delineate the boundaries between permissible state indoctrination and improper state interference in inherently religious areas. First, the schools should be able to indoctrinate values that relate to the political structure. Inevitably, there will be line drawing problems, but there should be an irreducible core of political beliefs that are deemed per se "not inherently religious" and that can be inculcated by the state. For instance, the state has the discretion to teach that the republican form of government is superior to other forms and that tolerance specifically in political matters is essential to the survival of democratic government. Concerns over partisanship and the ultimate propriety of this indoctrination can be best handled by general First Amendment doctrine. Obviously, some religious beliefs will be coerced by indoctrinating political beliefs, but as long as the courts recognize and endorse schools' socialization powers, some religious coercion will be inevitable.

Second, a traditional understanding of religion can be used to delimit the number of areas that are subject to Establishment Clause requirements. Using tradition as a test has the difficulty of being both underinclusive and overinclusive. The test is overinclusive as the trend toward secularism, whether in science or morality, tends to reduce the subject matters considered proper for religion. The test is underinclusive in that it assumes there are some areas that religion should not address. A tradition test may also discriminate against newer non-traditional forms of religion. Nevertheless, using tradition as a test helps to identify at least a certain sphere of human existence that cannot be coerced by the prevailing state orthodoxy.

In $M c$ Collum, the Supreme Court implicitly used a traditional understanding of distinctions between secular and religious indoctrination to invalidate the religious classes in question. ${ }^{166}$ The Court seemed to make a similar inquiry in Aguillard when it determined that creation science is essentially religious in nature, and has no independent scientific value. ${ }^{167} \mathrm{~A}$ tradition test applied to curricular areas would continue this trend.

For instance, the textbooks that discussed morality questions in Smith coincided with inherently religious issues. So do curricula

\footnotetext{
${ }^{268}$ See notes 97-99 and accompanying text.

${ }_{167}$ Aguillard, $107 \mathrm{~S} \mathrm{Ct}$ at 2582.
} 
that implicate views on salvation, eternal life and sex education. ${ }^{168}$ Math and science, on the other hand, are not considered inherently religious. ${ }^{168}$ Inherently religious categories also coincide with spheres of privacy that already receive some protection from state control. ${ }^{170}$

In inherently religious curricular areas, the state should be precluded from consciously advancing any substantive view to controversial issues, either directly or methodologically. If the state cannot educate in an area without advancing a substantive view on an inherently religious issue, it should not enter that area. The state does not have a sufficient interest in moral education to trump the protection of religious liberty. ${ }^{171}$

${ }^{168}$ See Gutmann, Democratic Education at 6, 107 (cited in note 48) (no neutral view of sex education).

${ }^{169}$ As the proposed test relies upon a traditional view of religion in order to define a minimum sphere of curriculum that should be free of state indoctrination, it accepts the traditional dichotomy between science and religion. This dichotomy is reflected in such decisions as Aguillard, where the Court did not consider it necessary to determine whether the Louisiana legislature correctly deemed "creation science" a legitimate theory for classroom use. Aguillard, $107 \mathrm{~S} \mathrm{Ct}$ at 2584. As "creation science" included inseparable religious elements, it was almost definitionally inappropriate for discussion in a science class. The prevalence of this distinction between science and religion in American society may be demonstrated more dramatically by the fact that the challenge to evolution by "creation science" has largely been carried out upon an ostensibly scientific level by religious conservatives committed to the scientific method. Freeman and Mensch, 2 Tikkun 70 (cited in note 144).

While relying upon the traditional distinctions between religion and science, this Comment does not address the genuinely difficult questions raised by science. For instance, there is a possibility that the dichotomy between religion and science may be untenable even in theory. Historically, modern science may have developed partially as a result of certain religious assumptions held during the Middle Ages. See J. Robert Oppenheimer, On Science and Culture, 19 Encounter 3, 4-5 (Oct 1962). Even today there is increased awareness that science does not exist in a vacuum and is intimately related to culture. Freeman and Mensch, 2 Tikkun at 69-70 (cited in note 144). Moreover, the teaching of science in a compulsory public school system may interfere as easily with religious choice as indoctrination in any other subject matter. Professor Gelfand has recognized that the teaching of evolutionary theory destroys certain fundamentalist belief systems. As a result, he proposes that the discussion of evolution be excluded from the compulsory public schools and left to voluntary higher education. Gelfand, $16 \mathrm{~J} \mathrm{~L} \mathrm{\&} \mathrm{Educ} \mathrm{at} \mathrm{308,} 336$ (cited in note 154).

Eliminating areas of the curriculum and teaching a variety of theories in scientific areas would, however, significantly disrupt both the curriculum and the educational process, and as such might raise more fundamental questions about the viability of the public school system. A public school system inevitably requires that some degree of religious coercion be endured.

170 See Griswold $v$ Connecticut, 381 US 479 (1965) (birth control); Roe $v$ Wade, 410 US 113 (1973) (abortion); Moore $v$ City of East Cleveland, 431 US 494 (1977) (definition of the family).

${ }^{171}$ See text accompanying notes $52-53$. 


\section{B. The Duty to Balance}

The area of moral education is certainly "inherently religious," but it is also an area in which the state's interest appears to be strong. In 1980 , more than 6,000 school systems offered values education. ${ }^{172}$ The Supreme Court has already made it clear that the Establishment Clause places substantive limits on what the state can communicate through education. The proposed test requires a state that chooses to educate in inherently religious areas to present a balanced discussion of the issue. Scrutiny of educators' motives is important, but the Establishment Clause requires more than just non-coercive motives; it requires non-coercive effects. The best judicial mechanism for assuring non-coercive effects is a requirement that schools educate in a balanced fashion. This position is consistent with general First Amendment free speech theory, which provides some protection from indoctrination. ${ }^{173}$ To the extent that the proposed test places an affirmative duty on schools, it is justified by the Court's own precedent which is sensitive to even slight coercion of student religious belief and the constitutional text that gives special protection to religion. ${ }^{174}$

A school would not be required to present every feasible position on an inherently religious issue; it could limit discussion for legitimate administrative reasons, most obviously, for lack of time. However, the systematic exclusion of a particular viewpoint may constitute an Establishment Clause violation if there are non-administrative reasons for the exclusion. ${ }^{175}$

What actually constitutes balanced treatment of an issue cannot be established by a rigid formula. The fact that various viewpoints do not receive "equal time" cannot be dispositive. The core constitutional concern is that schools demonstrate a variety of valid viewpoints that exist on a subject and refrain from promoting any one. ${ }^{176}$

172 Gil Sewall, Do Moral Values Belong in School?, Newsweek 58 (June 2, 1980).

${ }^{173}$ See Board of Education v Pico, 457 US 853 (1982) and section II of this Comment.

${ }^{174}$ Michael W. McConnell, Accommodation of Religion, 1985 S Ct Rev 1, 9. The Free Exercise Clause specifically protects religious exercise, of course, but the Establishment Clause, which was passed due to concerns over religious conscience singles out religion for special protection as well. See Schempp, 374 US at 256 (Brennan concurring) ("the role of the Establishment Clause [is] a co-guarantor, with the Free Exercise Clause, of religious liberty.")

${ }_{125}$ See Cruz $v$ Beto, 405 US 319, 322 (1971) (must have non-religious reason for not providing place of worship to particular prison inmates).

178 Professor van Geel, addressing only free speech concerns, identified certain values that a balanced presentation approach should promote: 1) adequate and objective coverage of an issue; 2) fair presentation of opposing views; and 3) reasonable allocation of time to 
Identifying various viewpoints and integrating them into textbooks is not an insurmountable task. The same kind of determinations are already made with regard to racial and cultural bias. Similarly, judicial review of a curriculum's balance, though difficult, is by no means impossible. Expert testimony can be used to determine what views are "essential" to provide an objective presentation. Justice O'Connor's objective person standard ${ }^{177}$ can be used to help determine whether the presentation of an issue is significantly unbalanced.

In implementing this standard of review, the burden should be on the plaintiff to make out a prima facie case of an Establishment Clause violation, after which the burden could be shifted to school authorities to prove legitimate educational reasons for their decisions. ${ }^{178}$ Motivation is relevant under the first prong of Lemon, but proof of a prohibited motive is not necessary to make out a claim. ${ }^{179}$ The remedies available to the court should be quite broad, similar to those available in equal protection cases. ${ }^{180}$

The primary objections to placing this affirmative balancing duty on the schools is that it increases judicial intervention, limits academic freedom by deterring teachers from discussing controversial areas, ${ }^{181}$ and creates impermissible discrimination between re-

opposing views. 62 Tex L Rev at 290 (cited in note 51). A balanced presentation requirement in the context of inherently religious areas also promotes these values.

177 See Corporation of Presiding Bishop v Amos, 483 US 327, 107 S Ct 2862, 2874 (1987) (O'Connor concurring). See also van Geel, 62 Tex L Rev at 291 (cited in note 51).

${ }^{178}$ Mt. Healthy City Board of Ed. v Doyle, 429 US 274, 287 (1977). The Mt. Healthy decision requires the plaintiff to make out a prima facie case, to which the state can respond with proof that it would have reached the same decision based upon legitimate reasons.

179 Various types of evidence may be appropriate in determining whether a violation has occurred. See Arlington Heights v Metropolitan Housing Corp., 429 US 252, 266-68 (1977), for types of evidence that are appropriate in the equal protection context: (1) evidence of effect (2) past history of decisions with bad effect; (3) evidence of events which may have prompted the decisions; (4) departure from normal procedures; (5) legislative-type history. See generally Strossen, 47 Ohio St L J at 380-81 (cited in note 63) for discussion of types of evidence that can be used to prove "effect": (1) testimony of students; (2) expert testimony; (3) reasonable student standard; (4) survey of student opinion. Again, the teaching of objective facts about a viewpoint should provide a defense, regardless of whether they offend different groups.

${ }^{180}$ Abram Chayes, The Role of the Judge in Public Law Litigation, 89 Harv L Rev 1281, 1298-1302 (1976). The courts have demonstrated broad powers in equal protection cases. See Milliken $v$ Bradley, 433 US 267 (1977) (courts can order state to pay for compensatory educational programs); Swann v Board of Education, 402 US 1 (1971) (courts may reassign faculty, redesign attendance zones, and order busing). There is already precedent in the equal protection context requiring teachers to attend special training sessions in order to remedy constitutional deficiencies in classroom teaching. See Vitz, Censorship at 85 (cited in note 10 ).

181 Strossen, 47 Ohio St L J at 393-94 n 298 (cited in note 63). 
ligions. ${ }^{182}$ Although these criticisms represent possible drawbacks to a balanced presentation requirement, they do not justify the present system's refusal to recognize some forms of state coercion.

When an affirmative duty is imposed on a school the possibility and need for judicial intervention clearly increases and can create significant disruption. But the courts have not hesitated from intervening in the public schools in past Establishment Clause cases, and the degree of judicial intervention required in this instance would not be any greater than that experienced in the equal protection context. ${ }^{183}$ Schools can avoid judicial intervention entirely by not inculcating values in religious areas until appropriately balanced curriculum materials are developed.

The concerns over limiting academic freedom and chilling discussion of controversial issues, ${ }^{184}$ though valid, do not defeat the proposed test. It is unlikely that the state will be unable to give a balanced presentation, but if curricula cannot in fact discuss an issue in a neutral fashion, then the issue should not be discussed in the coercive public school environment. The number of ideas discussed in schools may decrease somewhat, but if the cost of addressing more ideas is significant state coercion, then the costs outweigh the state's legitimate interests. Non-balanced discussion of controversial ideas is also not totally prohibited. Outside of the compulsory education context, at the higher education level, the state is free to discuss religious issues without maintaining neutrality.

Finally, the concern over discrimination between religions that might result if a particular viewpoint is not discussed is significant but does not have as much weight in the establishment context as in the free exercise context. Particular students who are coerced by the school's failure to present a specific viewpoint can possibly raise these claims under the Free Exercise Clause. ${ }^{185}$ Under the Establishment Clause, the courts should ensure only that a viewpoint is not excluded for non-administrative reasons.

The proposed test is designed specifically for the public school context, where the impressionable nature of the students has often led the courts to create special rules. As such, it is not a general

182 Dent, $61 \mathrm{~S} \mathrm{Cal} \mathrm{L} \mathrm{Rev} \mathrm{at} 922$ (cited in note 3).

183 See note 180.

184 Dent, $61 \mathrm{~S} \mathrm{Cal} \mathrm{L} \mathrm{Rev} \mathrm{at} 922$ (cited in note 3). A balanced presentation approach is somewhat analogous to the FCC's former fairness doctrine, which also may have restrained discussion. See, Lucas A. Powe, Jr., American Broadcasting and the First Amendment at 108-20 (U Cal, 1987).

${ }^{285}$ See note 157. 
proposal for reorienting Establishment Clause jurisprudence. What the test attempts to do is make Establishment Clause jurisprudence relevant to the public school, an institution probably not even contemplated by the Framers. ${ }^{186}$ The test responds to the traditional concern for religious minorities by recognizing that all minorities, whether religious or non-religious, need protection in the context of the modern public school. ${ }^{187}$ The test also attempts to ensure that religion will not be trivialized due to the expansive nature of the modern state and thus will continue to supply alternative conceptions of the public good for consideration in the marketplace of ideas.

\section{The Proposal Applied}

Application of this standard to the cases presented in section I, yields results different from those reached by the courts in some instances. The plaintiffs in Smith objected to the omission of religious references in history and social studies textbooks. The trial court banned the books because they "discriminate[d] against the very concept of religion. ..."18s A significant number of books were banned, indicating a pattern of problematic curriculum materials. But since the claims dealt with omission, the standard of review is the Lemon purpose prong. Since the plaintiffs provided no evidence of a specific motive to exclude religious viewpoints, the court should have objectively reviewed the books to ensure that no egregious factual inaccuracies or omissions discriminated against religion in general or one particular religion.

${ }^{186}$ The Court has moved beyond eighteenth century conceptions to develop its Establishment Clause jurisprudence. For instance, the Court has recognized that in a pluralistic modern state, the demands of conscience are broader than the narrower conceptions held by the Framers. See Philip B. Kurland, The Origins of the Religion Clauses of the Constitution, 27 Wm \& Mary L Rev 839, 856 (1986) (Framers were not concerned with right not to believe). Likewise, the Court abandoned strict separation in part due to the recognition that it was not a realistic theory in the context of the modern regulatory state. See Roemer, 426 US at 745 (1982) ("A system of government that makes itself felt as pervasively as ours could hardly be expected never to cross paths with the church."); Note, 91 Yale L J at 1198 (cited in note 144). The coercive nature of public education coupled with the unique way in which government speaks through curriculum demands special consideration by the courts.

${ }^{187}$ At one time, public education in this country was quite religious in nature and nonreligious students demanded special protection. Today, special concern may be needed for religious students also. See Robert Marquand, Moral Education, Christian Science Monitor $\mathrm{B} 1 \mathrm{col} 4$ (Jan 30,1987) ("[M]any educators say the ethic of values clarification ... has, in fact, become the establishment ethic in education schools and associations.") (emphasis in original).

${ }^{188}$ Smith v Board of Commissioners of Mobile County, 655 F Supp 939, 985 (S D Ala 1987), rev'd, 827 F2d 684 (11th Cir 1987). 
The plaintiffs in Smith also challenged the curriculum's treatment of moral values. The parents complained that the home economics texts taught that value formation was purely personal and subjective, and failed to acknowledge important influences like religion and family. Value formation is an area that traditionally has been considered within the purview of religion, even if not exclusively so. Thus, the public schools should not be allowed to teach value formation in a biased fashion. Unless the state can demonstrate that the textbooks will be used in a broader program of moral education, these texts constitute a pattern within the curriculum that presents an exclusive state message on a religious issue. Their use, therefore, should be prohibited.

In Mozert, the parents complained about basic reading textbooks, arguing that they promoted the themes of moral relativism, evolution, sex role reversal, and mental telepathy. It is not clear whether the textbooks reflected a specific pattern of curriculum choices, but the trial court found that "one story reinforces and builds upon the other throughout the texts and the series as a whole."189 Assuming a pattern of curriculum choices existed, there still was not any evidence of direct promotion or disparagement of a specific religious viewpoint. The remaining question is whether the pattern presents an exclusive view on a religious issue. The plaintiffs claimed that the textbooks reflected moral relativism. If this theme was in fact pervasive throughout the texts and no other kind of value formation was discussed, an Establishment Clause claim would be made out.

Claims regarding specific books as in Grove, and Williams, are on shakier ground. It is difficult to argue that inclusion of one book among other curriculum materials constitutes a pattern of exclusion or a state message of disparagement. The mere fact that the novel in Grove involved religious matters should not present Establishment Clause problems unless it is part of a broader pattern of curriculum choices. ${ }^{190}$ The scrutiny in Williams would be closer because it involved textbooks, but one set of textbooks may not be sufficient in itself to raise constitutional concerns if the school used a variety of books. ${ }^{101}$ Unless the books in question are used to propagate a certain view of a religious issue without discussion of

189 Mozert v Hawkins County Public Schools, 647 F Supp 1194, 1199 (E D Tenn 1986), rev'd, 827 F2d 1058 (6th Cir 1987).

190 Grove v Mead School District No. 354, 753 F2d 1528 (9th Cir 1985).

191 Williams $v$ Board of Education of County of Kanawha, 388 F Supp 93 (S D W Va 1975), aff'd without opinion, 530 F2d 972 (4th Cir 1975). 
corresponding views, and so long as there is no direct disparagement of specific tenets the mere inclusion of religious and antireligious matter in the curriculum should not be problematic.

\section{Conclusion}

The proposed constitutional standard prevents the state from indoctrinating in certain areas and from making statements explicitly aimed at religious beliefs. As such, it should only apply to practices that clearly stand out from primary and secondary education's main task of equipping citizens with basic academic skills. The test reflects the realistic recognition that, despite pure motives, neutral education is impossible.

In protecting the autonomy of individuals to form their own religious beliefs, the Court has focused on preventing even the first step toward a religious establishment. ${ }^{192}$ However, prohibiting establishments defined only in religious and anti-religious terms is an unrealistic approach to the coercive nature of public schools. Inordinate concentration on the formal categories of religious, nonreligious and anti-religious is at best incomplete; at worst, it is a smokescreen for enshrining the state's most recent attempt to impose religious uniformity.

Thomas Jefferson, a renowned separationist, considered it appropriate for society to promote values common to all religions. ${ }^{193}$ Horace Mann felt that the use of the Bible in the schools represented a mere non-sectarian guide to moral values. ${ }^{194}$ Eighteenth and nineteenth century courts would undoubtedly have considered both men neutral educators. Today, they would be considered controversial. In order to protect what James Madison termed the "full and equal rights of conscience,"18s the courts must be prepared to move beyond formalistic concepts and ensure that the Establishment Clause is not made a rubber stamp for today's prevailing orthodoxy.

192 Lemon, 403 US at 612.

${ }^{193}$ John P. Foley, ed, The Jeffersonian Cyclopedia at 593 (Funk \& Wagnalls, 1900).

${ }^{194}$ See Schempp, 374 US at 268-69 n 34 (Brennan concurring).

${ }^{195}$ Irving Brant, James Madison: Father of the Constitution 1787-1800 at 269 (BobbsMerrill, 1950). 